INFORMASI: Kajian Ilmu Komunikasi-ISSN (p) o126-065o; ISSN (e) 2502-3837

Vol. 48. No. 2 (2018). Pp.195-211. doi: https://doi.org/10.21831/informasi.v48i2. 21205

\title{
THE MEDIA FRAMING OF THE SELFIE BETWEEN MISS ISRAEL AND MISS LEBANON FROM CNN \& BBC TOWARDS THE POLITIC INTEREST
}

\author{
Sabrina Bawazier \\ fullofsabrina@yahoo.com \\ Lestari Nurhajati \\ lestari.n@lspr.edu \\ Stikom LSPR Jakarta
}

\begin{abstract}
An international controversy occurred after the selfie between Miss Israel and Miss Lebanon went viral. The Instagram post received many responds from public whether its positive or negative feedbacks, the selfie itself involves a group photo of the Miss Universe contestants that are Miss Israel, Miss Lebanon, Miss Slovak and Miss Japan. After the post was posted by Miss Israel and went viral, Miss Lebanon received many critics relating to her existence in the picture. She was then accused of violating the Lebanon policy for being in contact with an Israeli whereas there are strict rules against any form of association with Israel. The objective of this research is uncover the media framing between Miss Israel and Miss Lebanon 2015 selfie controversy. This research will analyze articles from two different media that are CNN and BBC that uses the framing theory by Entman, to solve the research problem through four steps of the theory that are to define problem, identify causal interpretation, make moral evaluations, and give treatment/ recommendations. This research result that the two news portal stand for is to acknowledge where they are from, CNN is from the United States whilst BBC is from the United Kingdom. The United States and Israel has always had a special relationship amongst them. America will often back up Israel in any aspects, in other hand UK does not share the same relationship with any of these countries.
\end{abstract}

Keywords: Miss Universe Controversy, Selfie, Public Diplomacy, Media Framing, Framing Analysis

\section{MEDIA FRAMING SWAFOTO ANTARA MISS ISRAEL DAN MISS LEBANON DARI CNN \& BBC MENUJU KEPENTINGAN POLITIK}

\begin{abstract}
Abstrak
Kontroversi di dunia internasional muncul setelah swafoto antara Miss Israel dan Miss Lebanon menjadi viral. Instagram mengirimkan tanggapan-tanggapan dari publik yang berisikan komentar-komentar negatif ataupun positif. Swafoto yang diunggah tersebut berisi foto sederet kontestan Miss Universe yang terdiri dari Miss Israel, Miss Lebanon, Miss Slovak dan Miss Japan. Setelah foto tersebut diunggah oleh Miss
\end{abstract}


Israel dan menjadi viral, Miss Lebanon menuai banyak kritikan yang berkaitan dengan keberadaannya dalam foto tersebut. Dia kemudian dituduh telah melanggar kebijakan Lebanon karena melakukan swafoto dengan warga Israel padahal telah ada aturan yang cukup jelas mengenai pelarangan bekerjasama dengan warga Israel. Tujuan dari penelitian ini adalah mengungkap framing media dari kontroversi swafoto yang dilakukan oleh Miss Israel dan Miss Lebanon 2015. Penelitian yang menganalisis artikelartikel dari dua media yang berbeda yaitu CNN dan BBC ini menggunakan teori framing model Entman. Selain itu, penelitian ini menggunakan empat tahapan dari teori model Entman untuk menjawab permasalahan penelitian yang ada, yaitu menentukan permasalahan, mengidentifikasi interpretasi, membuat evaluasi tentang moral, dan memberikan rekomendasi. Hasil dari penelitian ini adalah masing-masing portal berita tersebut berada pada pihak masing-masing dimana CNN berasal dari Amerika dan BBC berasal dari UK. Amerika dan Israel selalu berada apada hubungan bilateral yang baik. Amerika akan selalu mendukung Israel di segala bidang, sebaliknya UK tidak memiliki hubungan sebaik kedua negara tersebut.

Kata Kunci: Kontroversi Miss Universe, Swafoto, Diplomasi Publik, Media Framing, Framing Analisis

\section{INTRODUCTION}

Miss Lebanon and Miss Israel appeared to be in one frame or more known now as a "selfie" during the quarantine of Miss Universe 2015 which created an international controversy. This issue made headlines to several of media worldwide creating a massive media frenzy. Miss Israel who took the picture and uploaded on her social media created a major controversy involving Miss Israel 2014. In the group selfie was not only of them, also including Miss Israel, Miss Lebanon, Miss Japan and Miss Slovak where they were all smiling and posing in the same picture.

Israel sent Miss Doron Matalon as its representative in the Miss universe, the 23-year-old from Beit Arye made the title defeating other contestants in Israel. According to the official Miss Universe website (Contestants, 2016), Miss Israel 2014 has served two years as a sergeant in the Israeli Defense Forces, and was the assistant of the commander of Israeli Center Command. Whilst Lebanon was represented by Miss Saly Greige of El Koura, she competed the competition in the age of 26 , her background of education was Masters Degree in Civil Engineering. She was concerned with the prosperity of the Lebanese citizens.

According from the picture, the posted group selfie between the ladies showed that Miss Israel on the far left next to Miss Lebanon, then Miss Slovak sitting on the right side of Miss Lebanon holding up a cup she was holding whilst Miss Japan was posing standing up on the far right side. They were all wearing matching $\mathrm{T}$ shirts complete with their sashes, all looking beautiful posing for the selfie that they would never expected to be a controversy.

The rapid flow of social media made this issue an instant international dispute where people around the world easily responded and commented on the post, and creating their own perspectives and some spreading positive or even negative feedbacks. The first selfie was posted by Doron Matalon on the $11^{\text {th }}$ of January 2015 on her Instagram account with the caption : "Good morning from us! Miss Japan, Miss Slovenia, Miss Lebanon EI @ missunews@missuniverse @beautyschoolbs @belezasdouniverso@ @missuniversusa @ miss_isreal" from her post she received 401 comments that are either supporting her or supporting Miss Israel Sally Greige.

Comments left on both of the beauty queens post were full of people from either Israel or Lebanon expressing how they felt towards the selfie, some were happy seeing the two showing peace amongst each other while others were leaving rude comments about the selfie.

The reason why this simple selfie created 
an International controversy is that the conflict originally started way back after Israel declared their independence in 1948, the two conflicted countries declared war ever since and even Israelis were banned to enter the country. Lebanese citizen must obey a strict law stated that it is forbidden to communicate with an Israeli and they will be sentenced to jail if failed to do so, that includes saying hello to an Israeli while traveling. The law strictly forbids any forms of interaction from any circle of the Lebanese people to the Israeli, without negotiation or any other bureaucracy will be imprisoned (Totten, 2013).

In the pre eliminatory studies researcher found comments left by the Instagram users, After the post went viral Miss Lebanon received many pressures from the people of Lebanon calling her failed to hold the countries values and failed to accomplish the précised rules from Lebanon on not interacting nor engaging with an Israeli. She even received threat that her title of Miss Lebanon will be stripped off her because of this issue. She then posted on Instagram 6 days after Miss Israel's post, her side of the incident claiming that she didn't mean for the selfie to happen by posting her group selfie of just her, Miss Slovak and Miss japan.

She explained that the original selfie was just of them 3 when Miss Israel jumped in the photo or called photo bombed on their group selfie. In the caption she explained that she knew her grounds and was very cautious to avoid being in contact or in pictures with Miss Israel who tried several times to take a picture with her, when Miss Israel then successfully jumped in the picture that Miss Lebanon was having with Miss Slovak and Miss Japan that then was took to social media. She asked everyone to keep on supporting her in the conflict that she was facing, even though she received many hatred comments on how immature she was for posting her response on Instagram.

After the response from Miss Lebanon clarifying the selfie was not intentionally and how she clarified the situation by mentioning Miss Israel took the selfie with her off-guard.
Based on her caption she informed how she was the victim of situation, in response to her clarification Miss Israel then took it on social media expressing how she felt towards the situation.

Grinberg (2015) said a similar issue occurred on 2002 where Miss Lebanon Christina Sawwaya missed the Miss Universe competition because Miss Israel Yamit HarNoy was also competing, even though she was disappointed of not being able to compete she respected her country's law and values. Sawwaya then quoted "Everything is political when it comes to your country's sovereignty and borders." The year 2006 was also a year of conflict for the Miss Universe competition, the two conflicted countries Israel and Lebanon were also caught on camera posing luckily the organizers of Miss Universe were able to remove the pictures before it went to the media. Those were the days before social media was rapid, they managed to escape from the media.

Luckily Miss Lebanon stated on Facebook and Instagram post that the selfie that is viral wasn't an accident and she didn't mean that to happen, she then was able to be free from the punishment.

The controversy between the contestants happened in a beauty pageant where they came together representing each country, the annual event is held in different part of the world every year. Miss Universe 2015 pageant was held in Florida International University Miami, Florida. There were 88 contestants competing for the title of Miss Universe, beautiful women from countries all around the world with diverse beauty and culture, where each contestant represents their country with its own uniqueness bringing their country to the international arena.

Beauty pageants, whether on the local or global stage, are lively sites for the production and contestation of cultural meanings. The beauty queen is a person (typically a woman) chosen by a group of people to serve as a symbolic representation of their collective identity to a larger, often national, audience (King-O'riaini, 2007). 


\section{LITERATURE REVIEW}

Public diplomacy has various forms, specifically in this matter it is the Soft diplomacy or also known as soft power. An effort to promote or inform with a glimpse of trying to influence without any pressures or any intentional forcing methods and as stated in the article (Gilboa, 2001) : Diplomacy in the media age: Three models of uses and effects, Diplomacy \& Statecraft, with the aim of affecting their thinking and ultimately. Public diplomacy has been said as a form of propaganda, however According to Joseph Nye "the best propaganda is no propaganda", he believes that using soft power is non-coercive is how to do diplomacy through culture, foreign policy and politic values. Beauty pageants has resembled the soft diplomacy definition by showing the beauty and grace of the women representing each country.

Media framing is another way to influence a phenomena or an issue, it is created to have a free thought/perspectives towards anything that is portrayed and whether its good or bad. Framing allows everyone to have their own understanding towards information, news and any other forms of interpretations. Not only just that but media framing also manages to convince audience what to believe and what not to believe, leaving people to have wild thoughts amongst what information is given.

Below is the table of the media list of news about the controversy:

Table 1. The media coverage news of the phenomena / controversy between Miss Israel and Miss Lebanon.

\begin{tabular}{|l|l|l|l|}
\hline Number & media & Date & content \\
\hline 1 & NBC News & 18-Jan-15 & $\begin{array}{l}\text { Oh Snap!: Miss Lebanon Slammed for Selfie With Miss Israel Lebanese } \\
\text { television station Al Jadeed quipped that, since one of her hobbies is } \\
\text { reading, she should have read that Lebanon and Israel are enemies. }\end{array}$ \\
\hline 2 & telegraph UK & 18-Jan-15 & $\begin{array}{l}\text { Israeli beauty queen's selfie with Miss Lebanon during Miss Universe } \\
\text { contest causes stir : An Israeli Beauty Queens selfie cause problem } \\
\text { towards the Lebanon, the contestant from Lebanon may be stripped of } \\
\text { her title for consorting with the enemy. }\end{array}$ \\
\hline 3 & IBTimes UK & 18-Jan-15 & $\begin{array}{l}\text { Miss Universe 2014: Miss Lebanon under fire for posing for selfie with } \\
\text { Miss Israel, Saly Greige responds on Facebook }\end{array}$ \\
\hline 5 & Jpost & 18-Jan-15 & $\begin{array}{l}\text { Miss Lebanon denies taking photo with Miss Israel, says she 'photo- } \\
\text { bombed' her }\end{array}$ \\
\hline 6 & Yahoo News & 18-Jan-15 & $\begin{array}{l}\text { Miss Lebanon in hot water after selfie with Miss Israel : Miss Universe } \\
\text { controversial selfie at Miss Universe contest } \\
\text { contestants are keen to proclaim their desire for world peace, but this } \\
\text { year's Miss Lebanon has declared war after claiming Miss Israel muscled } \\
\text { in uninvited during aroup "selfie }\end{array}$ \\
\hline 7 & $\begin{array}{l}\text { Huffington Post } \\
\text { UK }\end{array}$ & 19-Jan-15 & $\begin{array}{l}\text { Miss Lebanon Saly Greige Faces Calls To Lose Title After Miss Israel } \\
\text { 'Photo-Bomb' Saly Greige might loose her title, mentioned that a } \\
\text { Lebanese media joked about her hobby of reading "she should read the } \\
\text { history of Lebanon-Israel }\end{array}$ \\
\hline
\end{tabular}


Sabrina Bawazier dan Lestari Nurhajati, The Media Framing of the Selfie between Miss Israel and ....

\begin{tabular}{|c|c|c|c|}
\hline 8 & $\begin{array}{l}\text { Washington } \\
\text { Post }\end{array}$ & 19-Jan-15 & $\begin{array}{l}\text { Miss Israel and Miss Lebanon appear in a selfie, sparking a new Mideast } \\
\text { conflict : a statement from gence France-Presse correspondent in Beirut } \\
\text { wrote that Miss Lebanon "appears to be gritting her teeth. }\end{array}$ \\
\hline 9 & $\begin{array}{l}\text { C h i c a g o } \\
\text { Tribune }\end{array}$ & 19-Jan-15 & $\begin{array}{l}\text { Miss Lebanon's selfie with Miss Israel stirs up controversy in Middle East: } \\
\text { Miss Lebanon, Saly Greige, is facing backlash back home after she posed } \\
\text { for a picture snapped by Miss Israel, Doron Matalon. }\end{array}$ \\
\hline 10 & Telegraph UK & 19-Jan-15 & $\begin{array}{l}\text { Israel v Lebanon: The dark truth behind 'that' Miss Universe selfie : The } \\
\text { selfie between the beauty Queens led to some angry Lebanese folk calling } \\
\text { for their country's contestant to be stripped of her title for 'consorting } \\
\text { with the enemy'. }\end{array}$ \\
\hline 11 & Hollywood Life & 19-Jan-15 & $\begin{array}{l}\text { Miss Lebanon Disses Miss Israel After Their Selfie Together : politics can't } \\
\text { be left behind at the Miss Universe pageant, Miss Lebanon Saly Greige } \\
\text { dissed Miss Israel after the selfie went viral calling It an unintentional } \\
\text { selfie }\end{array}$ \\
\hline 12 & CNN & 19-Jan-15 & $\begin{array}{l}\text { Miss Lebanon distances herself from photo with Miss Israel: Miss } \\
\text { Lebanon stayed cautious about her distance with Miss Lebanon, Miss } \\
\text { Universe organization expressed how "unfortunate" the controversy was. }\end{array}$ \\
\hline 13 & BBC.co.uk & 19-Jan-15 & $\begin{array}{l}\text { Miss Israel posts a selfie on Instagram with Miss Lebanon and causes an } \\
\text { online storm }\end{array}$ \\
\hline 14 & LA Times & 19-Jan-15 & $\begin{array}{l}\text { Miss Israel's photo with Miss Lebanon sparks controversy : David Siegel, } \\
\text { Israel's consul general for the southwestern United States, said it would } \\
\text { be natural for Miss Israel to take a picture with Miss Lebanon because } \\
\text { "Israelis have their hands outstretched in peace. }\end{array}$ \\
\hline 15 & Times of Israel & 20-Jan-15 & $\begin{array}{l}\text { Lebanon probes Miss Universe selfie row : Lebanese Tourism Minister } \\
\text { Michel Pharon told The Associated Press that "if there was bad intentions" } \\
\text { from Saly Greige, measures could be taken against her }\end{array}$ \\
\hline 16 & Telegraph UK & 23-Jan-15 & $\begin{array}{l}\text { Miss Lebanon will not lose her title for selfie with Miss Israel : Miss } \\
\text { Lebanon weathers political storm surrounding a selfie with Miss Israel, } \\
\text { as she accuses her rival of chasing her around for the photograph }\end{array}$ \\
\hline 17 & Times of Israel & 23-Jan-15 & $\begin{array}{l}\text { Miss Israel chased Greige for days': Miss Lebanon was recently } \\
\text { investigated after allegedly standing side by side with Miss Israel, Miss } \\
\text { Lebanon says Doron Matalon attempted to ambush her numerous times } \\
\text { to take joint photo }\end{array}$ \\
\hline 18 & Ynet News & 23-Jan-15 & $\begin{array}{l}\text { Miss Lebanon will not be stripped of title for Miss Israel selfie : Saly } \\
\text { Greige will not be have crown revoked for taking a selfie with Miss Israel } \\
\text { in incident which has sparked outrage around the world. }\end{array}$ \\
\hline 19 & Haaretz & 23-Jan-15 & $\begin{array}{l}\text { Miss lebanon keeps her crown despite selfie with miss Israel, the minister } \\
\text { stated that she should be supported because she "has been the subject of } \\
\text { a racist and random campaign" }\end{array}$ \\
\hline 20 & CNN & 25-Jan-15 & $\begin{array}{l}\text { A 'diplomatic' dance :when politics and beauty pageants collide, beauty } \\
\text { pageants embody global politics, with contestants expected to model the } \\
\text { cultural sensibilities of their nations. }\end{array}$ \\
\hline
\end{tabular}

Source: writer from varieaty source 2016

Especially now in the era of technology where media has fed people on their daily basis to basically frame information on any kind of media to then shape and guide our perceptions towards what the media is intentionally trying to make people understand from their point of view.

Therefore, with this phenomena of the selfie between Miss Israel and Miss Lebanon in the Miss Universe 2015 quarantine that created a stir in the International media, is to be analyzed in this thesis using the media framing and to establish how the media (CNN.com and BBC.co.uk) wants the world to think and react towards these phenomena. Also to discover how politics within countries could be represented by beauty pageant contestants as part of the countries duty to 
promote their country's interest through soft power diplomacy.

One of the previous research about The Framing of International Media on Islam and Terrorism (Yusof, Hassan, Osman 2013). In this research, researchers conducted a content analysis on two international news magazines looking at the tendency patterns in labeling Islam associated with terrorism after the death of Osama Bin Laden and also looking at the discourse analysis by extracting any recurrent themes emerged from the articles selected.

Researchers used two international news magazines namely The Economist from the UK and TIME from the US to be analyzed. They used these précised media based on several of reason consisting the US as a major superpower and an important player in the role of framing Islam and labeling it with terrorism, particularly after the September 11 attacks represent, it also is the supremacy of the western world in terms of social, political and military and their media have been made as reference by other countries. Whilst UK is selected due to its status as an economic power and holding strong political position particularly in the European region. With its long historical relationship with Islam and Muslim countries especially in the Middle East throughout 18 and 19 century, its media would have a unique dimension of the representation of Islam.

This study applied a content analysis as the research methodology in collecting, coding and analyzing the data. The researchers have analyzed 109 news articles both from Time and The Economist. The time frame of the study is just two months in which issues selected for both magazines are from the first issue after the death of Osama Bin Laden, until two months after that. The result of this study shows that Britain, Lexington, Obituary, Books and Arts, International and others where most of the articles related to Islam are located, the most of the headlines.

Another previous research about Journalism Curiosity and Story-telling Frame: A comparative study of Australian and Danish newspapers by Ebbe Grunwald Centre for
Journalism, Department of Political Science and Public Management, University of Southern Denmark and Verica Rupar Cardiff School of Journalism, Media \& Cultural Studies, Cardiff University UK .This research is a comparative study of journalism practices in Australia and Denmark explores the interplay between two concepts relevant for journalism's meaning-making activity: a curiosity seen as an action meant to close an information gap, and a story-telling frame seen as a form of structuring information which helps to define what is known of a topic. This study monitors the coverage and collect articles in four newspapers from Australia and Denmark. The differences between the Australian and Danish press become more transparent when one moves from the notion of frame towards the concept of angle. In the Australian press journalists emphasize the fact that the Tasmanian devils sent to Denmark were healthy. In the Danish press, the emphasis was on the character of the devils and the risk of disease.

The idea of "framing "offers a case study of just the kind of scattered conceptualization. The Analysis of frames illuminates the precise way in which influence over a human consciousness is exerted by the transfer (or communication) of information from one location-such as a speech, utterance, news report, or novel-to that consciousness (Entman R. , 1993).To frame is to select some aspects of a perceived reality and make them more salient in a communicating text, in such a way as to promote a particular problem definition, causal interpretation, moral evaluation, and/ or treatment recommendation for the item described 52). On Entman's following study he stated that from the four functions of framing above two is the most important which are problem definition which often virtually predetermines the rest of the frame and remedy or was recommendation because it directly promotes support (or opposition) to the problem (Entman R. M., 2003).

Framing essentially involves selection and salience, to frame is to select some aspects of a perceived reality and make them more 
salient in a communicating text, in such a way as to promote a particular problem definition, causal interpretation, moral evaluation, and/ or treatment recommendation for the item described. Frames define problems-determine what a causal agent is doing with what costs and benefits, usually measured in terms of common cultural values; diagnose causesidentify the forces creating the problem; make moral judgments-evaluate causal agents and their effects; and suggest remedies-offer and justify treatments for the problems and predict their likely effects (Entman R. , 1993, 52).

According to (Rana, 2011), Public Diplomacy as Activities through which governments working with non- state agencies, reach out to publics and nonofficial actors abroad, covering inter alia information, culture, education, and the country image. PD also includes the activities of the government directed at home publics, concerning foreign affairs and the image of its diplomatic network. He added that Public diplomacy covers cultural, media, education, tourism, and related activities, plus outreach to foreign and home publics. In an overall definition of Public diplomacy as an effort to influence covering all aspects cultural, foreign policy, ideologies and other forms produced in a country by utilizing the mass media or an influencer such as important people, icons and other representatives of the country.

Three concepts that deserve brief attention in a discussion on public diplomacy are propaganda, nation-branding and foreign cultural relations. Similar to public diplomacy, propaganda and nationbranding are about the communication of information and ideas to foreign publics with a view to changing their attitudes towards the originating country or reinforcing existing beliefs. Propaganda and nationbranding, however, neither point to the concept of diplomacy, nor do they generally view communication with foreign publics in the context of changes in contemporary diplomacy (Melissen, 2005, 16).

Diplomacy itself has been changing and reinventing themselves since the beginning, they use to be connected to war and military strategy to modern day diplomacy, through out the century diplomacy has constantly evolved. In saying so the only thing that evolves is the tools used and its focus and priorities rather than its definition and core aspects. Diplomacy and war is still related to how states interact, how they negotiate deals, how they regulate their relations with outside entities mostly over sovereign states, how they survive through a set of laws and conventions. However now technology has made an impact on the ways diplomacy is conducted (Sandre, 2015).

\section{Selfie as diplomacy And selfie as exposure on media coverage}

"Selfie" isatermused forthephenomenon of a photograph taken by the front camera, which has been gaining popularity as a global phenomenon and its usage is growing with technological advancements in front-facing cameras and photo-editing software, the continued stride in worldwide popularity has turned selfie into a global phenomenon (Shah \& Tewari, 2016). The Oxford English Dictionary 2014 named Selfie the "word of the year" for 2013 all because of the popularity of the phenomena (Hanson, 2016).

The phenomenon started as teenage vibe where teenagers made it popular on their social media accounts, it was believed as an obsession where it came to the attention that this phenomenon was actually dangerous and had extreme consequences in many cases. Many news reports showed that there many accidents caused by this phenomenon, people falling of cliffs, rivers, and buildings (Shah \& Tewari, 2016, 2)

Accidents caused by the phenomenon of selfie happened recently to a 16-year-old girl from Indonesia where she got hit by a train after her attempt of a selfie near a moving train, another tragic accident happened again to a junior High School boy who was taking his selfie on top of an unfinished 5 story building when he fell to death because there were no walls securing him (Liputan6, 2016). 
Due to the vast growth of technology it developed the term of digital diplomacy which utilizes the platform of social media to gain reputation and as a country branding through images of a country. The effectiveness of digital diplomacy is that social media engages a two way interaction, it is also said to achieve the foreign policy goals within the country (Bjola \& Holmes, 2015). Selfie diplomacy is an effort from national branding, as world nationals attempt to proactively manage their image reputation, analyzing a nations digital diplomacy channels may enable researchers to characterize nations selfie and illustrate the image it attempts to promote around the world, Selfie diplomacy is powerful as it reaches users worldwide.

The usage of selfie has increased more the just a self picture, it has developed as one of the tools in marketing to gain awareness through social media. Selfie is able to said as a social branding tool, where there is direct interaction towards customers and organizations (Meiselwitz, 2016). According Zaller (1992) political awareness can be thought of as a type of cognitive engagement and defines it as "the extent to which an individual pays attention to politics and understands what he or she has encountered" In his study he basically named politic interest as awareness.

Van Deth (200o) argues that there are two types of political interest : First, he argues that political interest can be thought of as the "degree to which politics arouses a citizen's curiosity" or "a citizen's attentiveness to politics." The second way to conceptualize political interest is in terms of political salience or "the relative importance of political matters compared with other activities" (119).

\section{METHODS}

This research is to study the media framing of the selfie taken during the Miss Universe quarantine by Miss Israel involving Miss Lebanon. A Qualitative approach with interpretative paradigm will be conducted in this research. Researcher utilizes the
Qualitative approach with interpretative paradigm in this study because interpretative approach allows researcher to interoperate a situation or phenomena through the researchers own sense and understanding, this approach will be compatible in this research due to answering the research problems.

To conclude this research of framing the media that covered the phenomena of the selfie between two conflicted countries, an interpretative paradigm will be used to help researcher interoperate the news. Besides that, framing is able to be subjective towards the way of seeing an object, news, or other source of information. Based on the individual preferences or the background that affects on how to portray the information.

The Unit analysis in this study utilizes online media which covers the news of the selfie between Miss Israel and Miss Lebanon phenomena. In this research the data collecting technique was to gather different news from different online medias. It then came up to the Top Ten online medias from the US and the UK. By Alexa. $\operatorname{com}(24 / 10 / 2016 / 17.26) \mathrm{CNN}$ is the number 1 rank online media in USA based on most visit, in other hand BBC is rank number 1 online media in UK. Writer decided to analysis the news coverage from US because of several of reasons, the phenomena happened in the country as it was the hosting country for the Miss Universe finals, another interesting fact is that the US engages with Israel and Lebanon. On the other hand, UK as another country that is reporting this phenomenon from a different country with obviously different perspectives and backgrounds.

According to telegraph.co.uk relationship between Britain-Israel used to be friendly, the relationship kept on being on and off due to Israel-Palestine dispute Britain was confirmed disgusted by the Israeli Jewish movement wanting totakeover Gaza. (Morris, 2014)whilst the relation between the US and Israel according to an article is in a positive phase where cooperation's amongst the countries remain smooth, another important key is that the two shared democratic values, 
on the popularity of Israel in American politics, or on the elusive pursuit of progress in the peace process. It is a relationship based on tangible interests -- and will remain so for the foreseeable future (Pollock, 2012).

(AIPAC, 2016) Americas Pro-Israel Lobby is a prove of the strong relationship between Israel and America, with their mission that unite the United States and Israel and how it is in America's best interest to help ensure that the Jewish state is safe, strong and secure. Another purpose of AIPAC is the promotion of a negotiated two-state solution - a Jewish state of Israel and a demilitarized Palestinian state. They believe that USIsrael is most reliable strategic partner in the middle east, sharing common threats occurring both countries. These threats range from terrorism, the spread of radical Islamist ideology and nuclear and missile proliferation to narcotics, counterfeiting and cyber warfare.

On the other hand, Lebanon is the country where Hezbollah is based in and is called as one of the threats that the US is trying to defeat along with Israel. Hezbollah is a military movement that has committed terrorist acts, large-scale fighting between Israel and Hezbollah in mid-2006 complicated U.S. policy toward Lebanon. In a broader sense, the conflict jeopardized not only the long-term stability of Lebanon but presented the U.S. government with a basic dilemma (Addis \& Blanchard, 2011).

\section{RESULTS AND DISCUSSION}

The dispute between these conflicted countries has been an ongoing issue, right after Israel declared their independence in 1948, the two conflicted countries declared war ever since and even Israelis were banned to enter the country. Lebanese citizen must obey a strict law stated that it is forbidden to communicate with an Israeli and they will be sentenced to jail if failed to do so, that includes saying hello to an Israeli while traveling.

Israeli leaders has even sent a message through American officials to the Lebanese
Government that it would be held responsible for any future war with Hezbollah and that no area or governmental institution would be off limits from the IDF's firing range (Rabil, The Challenge of Islamism, 2011).

It all began on the early 1948 Palestine war, where Israel and middle east or known as the Arab-Israel war affecting Lebanon, from Israel's attacks and occupation of Lebanese territory. Lebanon has avoided to get involved with the Arab-Israeli war that happened in 1967 and 1973 even though it has been affecting the country, however it failed to not get involved on 1970 where Lebanon became the battleground of the Israel Military forces and PLO (Palestine Liberation Organization). The 1982 Israel invasion was the most destructive conflict of the Arab-Israel war, the Israel army occupied the capital city of Lebanon. It was a challenge for Lebanon to make a decision because of the uncertainty destiny of the Palestine refugees and its entrenchment in the strategic Israel-Lebanon-Syria triangle. These were the barriers that affected domestic political scene and create divisions between those who favors ending the hostilities with Israel and the allies of Syria and Iran, those were also the barriers that prevents Lebanon from securing peace and progress through the delimitations of its frontiers to the south and the use of its water resources, despite the intervention efforts from the UN Interim Force in Lebanon (UNIFIL).

Another reason Lebanon has rejected to negotiate with Israel is to avoid turning the Palestinian refugees in Lebanon into permanent settlers, If these refugees became permanent residents in Lebanon, Lebanon's demographic balance would tip in favour of the Sunnis. Further more, since the PLO left Lebanon in August 1982 after it was defeated by the Israeli army, no solution has been found for the humanitarian, social, political or security-related problems of refugees living in impoverished camps (Ezzi, 2012).

Late May 2006 saw a further escalation, which began with a mysterious explosion of a kind that is commonplace in Lebanon. Hezbollah suspected the Israelis behind the 
assassination then it led to them reacting by launching an accurate Katyusha rocket on the Israel Air Force base on Mount Meron. Israel then agrees to stop the attack after the Hezbollah appealed to the United Nations Interim Force in Lebanon (UNIFIL) via the Lebanese government. However, the IDF's proposal forbidding Hezbollah from returning to their border positions after the firing had subsided was not taken up (Harel \& Issacharoff, 2008, 2-7)

Therefore, the dispute amongst these two conflicted countries Lebanon and Israel has been an ongoing and continuous event. Based on studies and data the actual reason behind the dispute is their fight for the territory. Lebanon that is part of the Arab countries that has a conflict with Israel, the involvement of Lebanon is based on its unity with the Arab countries. The conflict happened when the Arabs territory was taken by Israel which then escalated the war by involving Lebanon when the Israel made the country as their battle ground to fight with Palestine which is in the Arab countries unity.

According from the pageant center website, Miss Universe pageant originally started in 1952 at Long Beach California. Initiated by a swimsuit line Catalina that was very upset by Miss America Yolande Betbeze 1951 who refused to wear her swimsuit for the line exposure shoots after she was crowned. Catalina swimsuits was the pageants major business sponsor that had been supplying swimsuits for the contestants.

E.B. Stewart president of the Catalina Line was quipped by former Miss America Jacque Mercer to start its own pageant, that was then the birth of "Miss Universe" beauty pageant contest where its intention was to promote the swimsuits line. Catalina held its first pageant the year 1952 with thirty American women competing for Miss USA title and twenty-nine International contestants competing for Miss Universe title.

Histories were made along the way of the beauty pageant where in 1962 Miss Haiti the first black woman to make the semi-finals, in 1973 the first time Miss Universe was broadcasted live around the world via satellite where it launched the tradition of holding the Miss Universe pageants being televised live from exotic locations, as years go by the pageant has became a popular event. One of the historical moment of the Miss Universe Pageant was the first black woman crowned as Miss Universe 1977 Janelle Commissions from Trinidad - Tobago, whilst in 1995 Miss Universe pageant that was held in Africa crowned the first bi-racial woman Miss USA Chelsi Smith.

The year 1996 Miss Universe Pageants went through many changes towards the competition where it began to be modernized and glamorizing the triple crown system after it was bought by Donald Trump one of the known business legends who legitimately then owned the three sister pageants consists of Miss Universe, Miss USA and Miss Teen USA. From 1996-2015 the Miss Universe Organization was owned by Donald trump then by 2015 WME | IMG announced the acquisitions of the Miss Universe Organization from Donald Trump (Pageants, 2017). As quoted by (Callahan, 2006) Miss Universe, Inc. is just not a corporation, it is an International Organization that closely models the UN General Assembly form, if not in content beauty queens are seen as ambassadors who represents nation-states.

Pageants have been a political all along, the exclusive crowning of white women prior to 1984 was overtly political (Jones, 1997). She mentioned that it has been all political since beauty pageants had difference sights toward white and black contestants.

A former beauty pageant contestant and a scholar of International relations stated her opinion about the finals of Miss universe, "From strict security and protests to the formation of regional blocs, international pageants are as tense as a G-20 summit, with cross-cultural miscommunication, behind the scenes diplomacy, and deal making (Darden, 2013)". This statement was regarding the 2013 Miss universe finals that took place in Moscow, Russia. One of her statements was that sheagreed Miss Universe 
is just another form of an International organization, because of the blurry decisionmaking process, often contested, and in many ways reflect the underlying power relations and interests of the dominant countries. In this case similar to most international Organizations the United States is usually the country that actually dominates, as a matter of fact in Miss Universe specifically the pageant is co-owned by Donald Trump and NBC in that case Miss USA has won 8 times in 61 years excluding 5 wins by the U.S territory of Puerto Rico.

The contestants or in this case delegates have their duties and diplomatic functions that includes embodying their own cultures through their national costume performance carrying the value and showing the world a glimpse of their cultures. As for the host they also would benefit from the event by harnessing the worlds attention, the presence of world press, tourism ads aired in the 190 countries where the pageant is broadcasted, generating revenue for the hosting country, not only that but a successful pageant may also convince the International Media of the ability of the host to safely pull off a large event and this is surely part of the rationale for Russia hosting Miss Universe for the first time.

Diplomatic relations is also shown in beauty pageants, in the 2013 Miss Universe pageant in Moscow for example showed the present state of Russia's foreign policy, where Albania, Kosovo and Georgia was missing out of the pageant because Miss Kosovo could not issue a visa since the Russian Federation does not recognize the country as an independent state, Miss Albania withdrew from the competition as sign of political solidarity between ethnic compatriots, whilst the absence of Miss Georgia was because of the country's strained foreign relations with Russia (Darden, 2013).

Recent issue in Miss Universe 2017 hosted by the Philippines affected the competition, China was reportedly banned entering Manila because of the territory dispute between Philippines and China over South China Sea (Pinoy, 2016). However eventually the government allowed the Miss China to enter Philippines and compete in the finals.

Therefore with the facts and data mentioned about we can see that pageants are interrelated with politics and the interest of the countries they represent, without realising that these women competing are apart of their countries mission.

\section{Framing Analysis}

This research will utilize the framing by Robert Entman, by framing two online media that is from different contingents the United states CNN online news media and the United Kingdoms BBC online news media. This part of the research leads to the identification where each of the medias stand for and how these sources present their articles to the readers.

Table 2. Analysis Framing CNN news by Entman, 1993.

\begin{tabular}{|l|l|}
\hline & Material Framing \\
\hline $\begin{array}{l}\text { Problem } \\
\text { Definition }\end{array}$ & $\begin{array}{l}\text { The selfie between Miss Israel } \\
\text { and Miss Lebanon that caused } \\
\text { an International controversy. }\end{array}$ \\
\hline Causal & $\begin{array}{l}\text { The title of the article is } \\
\text { cornering Miss Lebanon } \\
\text { The story of the articles } \\
\text { direction is blaming Miss } \\
\text { Lebanon } \\
\text { The comments that the author } \\
\text { put in the article are those who } \\
\text { are pro Miss Israel. }\end{array}$ \\
\hline Moral Evaluation, & $\begin{array}{l}\text { The article does not mention } \\
\text { the whole story of the conflict } \\
\text { between the countries. }\end{array}$ \\
\hline Treatment \\
Recommendation & $\begin{array}{l}\text { The news coverage should have } \\
\text { stated the actual reasons why } \\
\text { Miss Lebanon distances herself } \\
\text { from Miss Israel. }\end{array}$ \\
\hline Source: witer, & 2016. \\
\hline
\end{tabular}

Source: writer, 2016.

Table 3. Analysis Framing BBC News by Entman, 1993.

Material Framing 


\begin{tabular}{|c|c|}
\hline $\begin{array}{l}\text { Problem } \\
\text { Definition }\end{array}$ & $\begin{array}{l}\text { The selfie between Miss Israel } \\
\text { and Miss Lebanon that caused } \\
\text { an International controversy. }\end{array}$ \\
\hline $\begin{array}{l}\text { Causal } \\
\text { Interpretation }\end{array}$ & $\begin{array}{l}\text { The article has met all the } \\
\text { requirements for the story, } \\
\text { its detailed information has } \\
\text { covered the actual problem. } \\
\text { The article did not inform/ } \\
\text { explain the state policy of } \\
\text { Lebanon. }\end{array}$ \\
\hline Moral Evaluation, & $\begin{array}{l}\text { The article remains neutral } \\
\text { in covering the issue of the } \\
\text { controversy. } \\
\text { The article gives an } \\
\text { understanding towards the } \\
\text { situation between the both } \\
\text { countries. }\end{array}$ \\
\hline $\begin{array}{l}\text { Treatment } \\
\text { Recommendation }\end{array}$ & $\begin{array}{l}\text { The article should inform more } \\
\text { about how the controversy } \\
\text { occurred. } \\
\text { The article should've } \\
\text { mentioned why the controversy } \\
\text { has started in the first place. }\end{array}$ \\
\hline
\end{tabular}

Source: writer, 2016.

The two tables above show how the two different news portal portrayed the news about the controversy that happened between Miss Lebanon and Miss Israel. There are different sides to every story, in this research particularly researcher is aiming to frame the news from two massive news portal $\mathrm{CNN}$ and BBC.

CNN describes the selfie controversy as an unfortunate event that happens to be a fault from Miss Lebanon where she distances herself from Miss Israel, when the whole pageant of Miss Universe is to keep peace upon everyone without mentioning the state policy of a certain country in this case Lebanon. The articles direction of covering the story did not meet the neutral aspect of the story, they did not explain about their real conflict between the two conflicted countries, in other words the title mislead the article in giving in mind that Miss Israel was the victim of Miss Lebanon.

BBC covers thearticle in a neutral manner where they explained the conflict and the war history detailed with the map that was the actual conflict in the first place. The title also showed that they were not in any directions of blaming or taking sides at all. However the important aspect of the story was missed out from the article, the state policy that was one of the reason the controversy started in the beginning which is the Lebanese citizen must obey a strict law stated that it is forbidden to communicate with an Israeli and they will be sentenced to jail if failed to do so, that includes saying hello to an Israeli while traveling. The law strictly forbids any forms of interaction from any circle of the Lebanese people to the Israeli, without negotiation or any other bureaucracy will be imprisoned (Totten, 2013).

This is is why Miss Lebanon had to distance herself and not have contact with fellow contestant from Israel. On her Facebook page she wrote that she knew well about the policy and she did everything she could to stay away from Miss Israel until this accidental selfie that happened between the two. She then apologized to her people regarding the issue and asks for their support for her to compete in the competition.

In a broader evaluation selfie is a form of an individual to show certain things in public that could be an item that their wearing or just a simple way to show themselves of physically through the self portrait and usually be updated on social media. Due to the vast growth of technology it developed the term of digital diplomacy which utilizes the platform of social media to gain reputation and as a country branding through images of a country. The effectiveness of digital diplomacy is that social media engages a two way interaction, it is also said to achieve the foreign policy goals within the country (Bjola \& Holmes, 2015).

Technology has brought a large impact to the life we live in today, diplomacy activity was used to be known as a representative from a country visiting another country to pass on the message sent from the originate country. Whilst now diplomacy easily be shown by pictures taken from the specific country and shared to the whole world. An easy example was the selfie between presidents that has been a trend lately, that is also a diplomacy from the presidents involved in the selfie and trying to spread a message that we are all in 
good terms. Another easy example is visiting countries tourism destinations where they inform to use hashtags on the pictures taken at the location.

Specifically, in the topic of gaining awareness within certain organizations, in this matter Miss Universe as an international organization used many platform as a promotion effort. Instagram has been one of the source of the promotion efforts showing the daily activities of the pageants and even to introduce the contestants. Therefore, selfies are important to be taken in events it helps gain awareness and helps supports the brands of sponsors that contributes in the events or as a media coverage for the event. Through the modern and digital era, diplomacy or diplomatic activities also utilizes the "selfie" phenomena where head of countries show a certain image on their current location, a friendly site of 1 or 2 head of countries share an image to show public their relationship with each other. Whilst in this matter the selfie itself stirred up an international controversy because of the relationship between the representative was not on a good term.

The politic interest is to gather or gain awareness, in the topic of pageants woman from all around the country has a mission from each countries they represent which is to win the title of Miss Universe. The main goal and interest that is embedded in the minds of the contestants is to bring the crown home and become the next Miss Universe finals host. The other objective from Deth is the citizens attentiveness to politics, meaning that political activities must gain the attention from the people with the country. The attentiveness of the citizens will then get involved to what the certain country is aiming for, in other words so that the people knows what is happening.

Official policy of Israel is to maintain friendly relations with the two superpowers required considerable caution in foreign policy activity, demands equal care and consideration in internal public pronouncements. Israeli political activities concerns on two main areas; first, their votes and posture at the U.N. second are their approach towards the establishment of military strategic alliances in the middle east and the decisions regarding their own participation (Brown, 2004, p. 121).Israel is part of the middle east in its ultimate foreign policy goals. This is accordance to the main patterns of middle eastern countries (and indeed most others) states in seeking security and wellbeing for Israelis but also Jews worldwide. Since the beginning, the policy of Israel has been characterized by a general consistency of policy objectives, a constant approach, and continuity in substance, despite the changes in styles of governments or governors for the first five decades of independency. The core goals is to achieve peace, universal recognition and acceptance, security and economic also welfare.

Through out five decades Israelis policy of foreign and security policy has primary goals first is to enhance the security of the state, second is to establish, sustain, and expand peaceful relations with the Arab States of the Middle East and North Africa not only neighbours that are near boarders but also broader Arab world. This will able to maintain the overall security of the state, further more would achieve a goal for Israel that is to lighten geographic isolation of Israel within its region and facilitate trade or other exchanges with its neighbours. Third is to protect the Jewish minorities around the world to maintain a relationship or a sustained link between the people and Israel as the only Jewish state in the world. In other worlds Israel will secure and assure Jewish immigrations that are endangered to be placed in Israel or at least in a safer locations. This will accommodate Jewish communities and contributes to the wellbeing of Israel (Brown, 2004, 125).

Lebanon, Israel, Iraq, Jordan, Syria and a prospective Palestine is amongst the countries that is known as the mosaic trope region because it fits well the fertile crescent. Amongst the countries Lebanon stands out as the extreme example of the diverse religion, there is no majority of religion within the country. The country's religious 
diversity lies at the heart not just of domestic politics but of its foreign policy. That is why the diplomatic impact of these religious differences has been that the Muslims identified with neighbouring Muslim Arabs, whereas Christians specifically Maronite's finds Lebanon more attached to France and the West (Brown, 2004, 281)

The Arab-Israeli conflict, the Cold War in the Middle East, and the evolving demographic and relative power situation within Lebanon, are amongst the histories of Lebanon. Since the mid 1940s, these were the three interacting developments that strikes the national treaty within the country. The impact of Arab Israeli war on 1948 brought in thousands of Palestinian refugees to Lebanon, most of them were living in refugee camps. With the tremendous total of Muslims from Palestine, Lebanon would face an unbalanced religious community. Therefore, it was difficult for the Palestinians to be granted with a citizenship, but the few exceptions were those who were Christians would begranted for a citizenship in Lebanon. Then Palestinians remained a politically alien and alienated population in Lebanon. Meanwhile, even though Lebanon has obeyed the Arab states agreement on the war against Israel, the Lebanese attitudes towards Israel remained indecisive and leans along lines of religious beliefs. Lebanon could not be a state serving as a haven for Christian Arabs, just as Israel was put forward as a haven for Jews. In any case, a neighboring non-Muslim state could perhaps serve as a counterweight to possible pressures from the Arab states with their decisive Muslim majorities (Brown, 2004, p. 282).

The researcher highlighted findings that will support the problem of this current research. The findings consist of specific matters that are the dispute between Lebanon and Israel, politics in Beauty pageants, concept of selfie, and the political interests of both countries. The reason behind the dispute is the fight over territory, Lebanon that is part of the Arab countries, the Arab Unity a conflict with Israel therefore the involvement of Lebanon is based on its unity with the Arab countries. After the problem occurred the state policy of Lebanon forbids Lebanese citizen to engage with an Israeli, by any form of communication those who violate will be punished by the country (Totten, 2013).

In this particular research one of the facts is that International beauty pageants have been associated as a form of International organizations that brings missions through contestants even though they might not realize (Callahan, 2006). Pageants have been a political all along, the exclusive crowning of white women prior to 1984 was overtly political (Jones, 1997). She mentioned that it has been all political since beauty pageants had difference sights toward white and black contestants.

The other highlighted findings that supports this research is to know the concept of selfie, selfie is a new form of public diplomacy, it can be utilized as a diplomatic gesture to maintain relationships or promote the countries worldwide and to gain awareness it is powerful as it reaches users worldwide (Bjola \& Holmes, 2015). These efforts are needed for countries to reach their politic interest, Political interest is seen often as a way for countries to get attention, many countries compete to get worldwide acknowledgement by its political interest (Zaller, 1992).

To support the research is also by understanding the two conflicted countries Israel and Lebanon goals and political interests, Israelis goals are to enhance the security of the state, also is to establish, sustain, and expand peaceful relations with the Arab States of the Middle East and North Africa not only neighbours that are near boarders but also broader Arab world. Their keen on having a good relationship with the Arab countries Israel (Brown, 2004, p. 125). Lebanon has a focus on the diverse religion within the country, whereas Muslims maintain a peaceful relationship with neighbouring Muslims states while Christians maintain its peaceful relation with Christian neighbouring states Israel (Brown, 2004, 283). 


\section{CONCLUSION}

Based on the analysis and discussions of the research, this chapter will solve and answer the research problem of this research. Through analysing the issue of the media framing of the selfie between Miss Israel and Miss Lebanon from two major news online portal CNN and BBC towards their political interests. In this particular chapter researcher explains how the media framing describes the selfie between Miss Israel and Miss Lebanon as that is the problem of the research.

To understand where the two news portal stand for is to acknowledge where they are from, CNN is from the United States whilst BBC is from the United Kingdom. The United States and Israel has always had a special relationship amongst them. America will often back up Israel in any aspects, UK does not share the same relationship with any of these countries.

In this particular research, researcher analysed that $\mathrm{CNN}$ was defending Israel on the controversy of their selfie. The articles title itself has cornered the Lebanon contestant by saying "Miss Lebanon distance herself from photo with Miss Israel", comments quoted in the article were all blaming Miss Lebanon and making it look that she shouldn't act as how she did. It did not give the information on Miss Lebanon's act towards the selfie she appeared in with Miss Israel.

On the other hand, BBC remained neutral in covering the whole story. It detailed its story with Arab map and explained its history among the two countries. The article consist of details needed to understand why the incident happened in the first place, the title "Miss Israel posts a selfie on Instagram with Miss Lebanon and causes an online storm" is the actual description without misleading the situation.

However the two articles did not mention the actual reason and the most important fact about why Miss Lebanon acted how she did, the main reason was that she had to do what she did by distancing herself because of specific strict rule that applied in Lebanon. The state policy forbids any form of contact with an Israel, that is why she stayed away from Miss Israel from the beginning of the Miss Universe quarantine. She explained the situation on Facebook after the Lebanese citizens criticized her for appearing in one frame with the nations enemy. The Facebook status was an apology to public and a message for her people to keep on supporting her through the completion. .

The facts that the researcher have found in this research has been supported by history data that evaluated the analysis by researcher. CNN as a news platform with most views in the US has showed its directions of covering the story. Israel and America has a special relationship amongst each other whereas America has always supported Israel in any condition.

Therefore to be able to answer the research problem on how the media framing describes the selfie between Miss Israel and Miss Lebanon through the articles from CNN and $\mathrm{BBC}$, researcher discovered that there are two different ways of the news portal in covering the story. $\mathrm{CNN}$ has made the articles direction in cornering Miss Lebanon about the situation of the controversy by informing more of Miss Israel's side supported by comments from public. On the other hand, $\mathrm{BBC}$ has made the decision in covering the story by detailing the full situation of the controversy without cornering both of the ladies.

\section{REFERENCES}

About Us. (2017). Retrieved April 5, 2017, from Miss Universe Website: https:// cms.missuniverse.com/pages/aboutus

Addis , C. L., \& Blanchard, C. M. (2011). Hezbollah: Background and Issues for Congress. Congressional Research Service. www.crs.gov.

AIPAC. (2016). (The American Israel Public Affairs Committee) Retrieved October 25, 2016, from AIPAC: http://www. aipac.org

Bjola, C., \& Holmes, M. (2015). Digital Diplomacy: Theory and Practice. 
London, England, UK: Routledge.

Brown, L. C. (2004). DIPLOMACY IN THE MIDDLE EAST. New York, United States: B.Tauris \& Co Ltd.

Callahan, W. A. (2006). Cultural Governance and Resistance in Pacific Asia. USA: Routledge.

Conolly, J. (2015, January 20). Articles. Retrieved October 20, 2016, from BBC : http://www.bbc.co.uk/newsbeat/ article $/ 30878930 / \mathrm{miss}-$ israel-postsa-selfie-on-instagram-with-misslebanon-and-causes-an-online-storm

Cresswell, J. W. (2009). RESEARCH DESIGN Qualitative, Quantitative, and Mixed Methods Approaches. Thousand Oaks, California, United states of America: SAGE Publications, Inc.

Darden, J. T. (2013, November 8). Retrieved June 5, 2017, from Foreign Policy: http://foreignpolicy.com/2013/11/o8/ what-does-miss-universe-2013-tell-usabout-world-politics-in-2013/

Entman. (1993, December). Framing: Toward Clarification of a Fractured Paradigm. Journal of Communication, 43(4), 51-58.

Entman, R. M. (2003). Projections of Power: Framing News, Public Opinion, and U.S. Foreign Policy. Chicago, USA: University of Chicago Press.

Ezzi, G. E. (2012). Positive peace for Lebanon: reconciliation, reform and resilience. (E. Picard, \& A. Ramsbotham, Eds.) Accord(24), 73-75. Retrieved from Conciliation Resources : http:// www.c-r.org/downloads/Accord24_ IsraelandPeaceinLebanon.pdf

Gilboa, E. (2001). Diplomacy in the media age: Three models of uses and effects. Diplomacy \& Statecraft, 30.

Grinberg, E. (2015, January 26). (Turner Broadcasting System, Inc) Retrieved September 20, 2016, from CNN International Edition: http://edition. cnn.com/2015/o1/25/living/feat-missuniverse-beauty-pageants-politics/
Hanson, J. (2016). The Social Media Revolution. Santa Barbara, California, USA: Greenwood.

Harel, A., \& Issacharoff, A. (2008). $34 D A Y$ ISRAEL, HEZBOLLAH, AND THE WAR IN LEBANON (Vol. I). United States of America: PALGRAVE MACMILLAN.

Jones, K. (1997). Women Transforming Politics. USA: New York University Press.

King-O'riaini, R. C. (2007). Making the Perfect Queen: The Cultural Production of Identities in Beauty Pageants. sociology compass, 74 .

Liputan6. (2016, Mei 5). News. Retrieved September 24, 2016, from Liputan 6: $\quad$ http://news.liputan6.com/ read/2500293/selfie-di-gedungkosong-koja-bocah-smp-tewas-jatuhdari-lantai-5

Meiselwitz, G. (2016). Social Computing and Social Media. USA: Springer.

Melissen, J. (2005). The New Public Diplomacy: Soft Power in International Relations. New York, USA: PALGRAVE MACMILLAN.

Miss Universe. (2016). (Miss Universe) Retrieved September 24, 2016, from (c) 2016 IMG Universe, LLC. : http://www. missuniverse.com

Morris, B. (2014, August 11). news. (Telegraph Media Group) Retrieved October 25, 2016, from The Telegraph: http://www. telegraph.co.uk/news/worldnews/ middleeast/israel/11024978/When-didBritain-lose-faith-in-Israel.html

Nye, J. J. (2008, March). Public Diplomacy \& Soft Power. Annals American Academy of Political and Social Science, 616, 94109.

Pageants. (2017). Retrieved April 5, 2017, from Pageantcenter.com: http:// pageantcenter.com/miss_universe pageant.html

Pinoy, Pol. (August 4, 2016). https:// adobochronicles.com/2016/o8/o4/ 
philippines-bans-china-fromparticipating-in-the-2017-missuniverse-pageant-in-manila/ (accessed September 20, 2017).

Pollock, M. E. (2012, November 7). policyanalysis. (The Washington Institute for Near East Policy) Retrieved October 25, 2016, from The Washington Institute: http://www.washingtoninstitute.org/ policy-analysis/view/friends-withbenefits-why-the-u.s.-israeli-allianceis-good-for-america

Rabil, R. G. (2011). Religion, National Identity, and Confessional Politics in Lebanon (1st Edition ed.). New York, USA: PALGRAVE MACMILLAN.

Rana, K. S. (2011). 21st Century Diplomacy. (L. Lloyd, Ed.) London, UK: The Continuum International Publishing Group.

Sandre, A. (2015). Digital Diplomacy. USA: Rowman \& Littlefield.

Shah, R., \& Tewari, R. (2016, July 2016). Demystifying 'selfie': a rampant social media activity. Behaviour \& Information Technology, 8.

Totten, M. J. (2013, July). Article. Retrieved September 20, 2016, from The Tower: http://www.thetower.org/article/ dreaming-of-a-lebanon-completely-atpeace/

Trochim, W., \& Donnelly, J. P. (2006). The Research Methods Knowledge Base (3rd Edition ed.). Cengage Learning.

Van Deth, J. W. (2000). Interesting but Irrelevant: Social Capital and the Saliency of Politics in Western Europe. European Journal of Political Research.

Zaller, J. R. (1992). The Nature and Origins of Mass Opinion. USA: Cambridge University Press. 